\title{
PENERAPAN PENDEKATAN KONTEKSTUAL BERBANTUAN MEDIA KONKRET UNTUK MENINGKATKAN AKTIVITAS DAN HASIL BELAJAR
}

\author{
I Made Suarjana ${ }^{1, *}$, Ni Pt. Nanci Riastini ${ }^{2}$, I Gst. N. Yudha Pustika ${ }^{3}$ \\ 1 Jurusan Pendidikan Guru Sekolah Dasar. Universitas Pendidikan Ganesha, Indonesia \\ 2 Jurusan Pendidikan Guru Sekolah Dasar. Universitas Pendidikan Ganesha, Indonesia \\ 3 Jurusan Pendidikan Guru Sekolah Dasar. Universitas Pendidikan Ganesha, Indonesia
}

\begin{abstract}
Abstrak
Penelitian ini bertujuan untuk mengetahui peningkatkan aktivitas dan hasil belajar matematika siswa kelas SD 1 Blahkiuh. penelitian tindakan kelas yang dilakukan dalam dua siklus. Subyek penelitian ini adalah siswa kelas IV Sekolah SD 1 Blahkiuh yang terdiri dari 28 orang. Objek dari penelitian ini adalah aktivitas dan hasil belajar matematika siswa kelas IV semester II SD 1 Blahkiuh. Data dikumpulkan melalui lembar observasi dan data mengenai hasil belajar dikumpulkan melalui tes berbentuk uraian. Hasil penelitian ini dapat menunjukkan bahwa penerapan pendekatan kontekstual berbantuan media konkret dapat meningkatkan aktivitas dan hasil belajar matematika siswa kelas IV SD 1 Blahkiuh. Rata-rata aktivitas belajar pecahan bagi siswa pada siklus I mencapai 63,3\% dengan kategori cukup aktif dan meningkat pada siklus II dengan rata-rata aktivitas belajar pecahan bagi siswa adalah sebesar 77,8\% dengan katergori aktif. Untuk hasil belajar pecahan bagi siswa juga mengalami peningkatan terbukti dari tes awal rata-rata persentase hasil belajar pecahan bagi siswa hanya mencapai $48,75 \%$ dengan kategori kurang, kemudian siklus I rata-rata hasil belajar pecahan bagi siswa mengalami peningkatan sebesar 64,28\% dengan kategori cukup, dan di akhir siklus II rata-rata hasil belajar pecahan bagi siswa mencapai 78,57\% dengan kategori baik.
\end{abstract}

\author{
Keywords: \\ pendekatan kontekstual, \\ media konkret, aktivitas \\ dan hasil belajar
}

\section{Pendahuluan}

Pendidikan merupakan usaha sadar untuk menyiapkan peserta didik melalui kegiatan bimbingan, pengajaran, dan latihan bagi peserta didik di masa yang akan datang. Untuk meningkatkan mutu pendidikan di Indonesia telah diupayakan dengan berbagai cara atau strategi oleh pemerintah. Upayaupaya pemerintah tersebut sudah merambah hampir ke semua sarana pendidikan seperti: penambahan jumlah buku-buku pelajaran, peningkatan kualitas guru, pembaharuan kurikulum dan peningkatan kualitas pembelajaran yang mencakup pembaharuan model, metode, pendekatan dan media dalam kegiatan pembelajaran khususnya di tingkat sekolah dasar (SD).

Proses pembelajaran yang optimal dapat tercermin dari keterlibatan siswa secara menyeluruh dalam proses pembelajaran. Keterlibatan yaOkeng dimaksud disini adalah pembelajaran berpusat pada siswa dan peran guru adalah sebagai motivator dan fasilator yang bertugas memotivasi siswa, menyediakan fasilitas penunjang pembelajaran berupa media dan sumber belajar. Secara tidak langsung pembelajaran di kelas akan menjadi optimal dengan dihadirkannya fasilitas penunjang pembelajaran. Selain itu ditekankan oleh Dimyati dan Moedjiono (1994) bahwa pembelajaran yang optimal yaitu: pembelajaran dengan menggunakan metode atau model dan media belajar yang tepat, artinya bahwa di dalam melaksanakan proses pembelajaran ada beberapa faktor penentu keberhasilan dalam meningkatkan kualitas pendidikan di sekolah dasar antara lain: proses pembelajaran, guru, siswa, sarana dan prasarana dalam melakukan kegiatan pembelajaran, lingkungan siswa di sekolah dan sumber belajar.

Pendapat di atas di dukung pula oleh Arsyad (1997) yang menyatakan bahwa dalam metodelogi pengajaran ada dua aspek yang menonjol yakni metode dan penggunaan media yang sesuai. Berdasarkan kedua pendapat tersebut sudah jelas tersurat bahwa untuk menciptakan pembelajaran yang optimal harus memikirkan media yang sesuai dengan materi pembelajaran. Pendidikan di sekolah dasar merupakan pendidikan tahap awal dalam jenjang pendidikan nasional. Disinilah akan dibangun konsep-

\footnotetext{
* Corresponding author.

E-mail Addresses imade.suarjana@undiksha.ac.id (I Made Suarjana) putunanci.riastini@undiksha.ac.id (Ni Pt. Nanci Riastini),

gustingurah@yahoo.com (I Gst. N. Yudha Pustika)
} 
konsep awal tentang pengetahuan siswa yang hendaknya dilakukan secara benar dan tepat. Di Sekolah Dasar terdapat beberapa mata pelajaran yang diajarkan salah satunya adalah matematika.

Pendidikan matematika mempunyai potensi besar dalam mempersiapkan sumber daya manusia yang berkualitas untuk menghadapi era globalisasi. Potensi ini bisa terwujud jika pendidikan matematika mampu menjadikan siswa yang cakap dalam penguasaan konsep-konsep matematika. Rendahnya mutu pendidikan di Sekolah Dasar telah diantisipikasi oleh pemerintah dengan mengadakan berbagai upaya mulai dari perbaikan kurikulum pendidikan sampai dengan meningkatkan kualitas tenaga pendidiknya dengan cara memberikan diklat atau penataran. Pembelajaran matematika di Sekolah Dasar merupakan pondasi yang kokoh untuk dapat memasuki jenjang pendidikan yang lebih tinggi dan peranan matematika terus berlanjut hingga zaman globalisasi sekarang. Perkembangan ilmu pengetahuan dan teknologi modern dewasa ini tidak terlepas dari peranan matematika, karena pada dasarnya matematika mampu meningkatkan kemampuan untuk berpikir dengan jelas, logis, teratur, dan sistematis (Depdiknas, 2002).

Pembelajaran matematika sampai sekarang ini masih merupakan mata pelajaran yang ditakuti oleh sebagian anak didik. Hal ini disebabkan oleh cara memahami itu masih belum tepat terutama pada tahap pembelajaran awal. Menurut Sudiana (2004),"konsep-konsep matematika itu diperkenalkan lewat pengalaman manipulasi kolompok-kelompok benda nyata dan alami." Jika sejak permulaan matematika itu diajarkan secara abstrak tentu akan menakutkan anak didik, sebab anak didik belum mampu memikirkan bilangan secara abstrak. Jadi dalam hal ini pembelajaran matematika perlu alat bantu, yaitu benda-benda nyata yang dapat diolah, dimanipulasi dalam bentuk, jumlah dan penglompokan. Di Sekolah Dasar peranan matematika yang begitu besar ternyata tidak sesuai dengan proses dan hasil pembelajaran matematika pada siswa. Kebanyakan siswa menganggap matematika sulit dipelajari. Pitajeng (2006) menyebutkan bahwa siswa juga berpendapat gurunya kebanyakan tidak menyenangkan, membosankan, menakutkan, angker, killer, dan sebagainya.

Sesuai dengan uraian diatas, pembelajaran matematika di Sekolah Dasar Nomor 1 Blahkiuh juga memiliki permasalahan. Hal ini diketahui dari hasil observasi awal yang dilakukan pada tanggal 2 November 2010, dengan mengamati proses pembelajaran matematika yang berlangsung di kelas IV. Adapun permasalahan yang dapat diidentifikasi adalah sebagai berikut. 1) Siswa kurang aktif dalam mengikuti proses pembelajaran di kelas baik dalam hal mengajukan pertanyaan dan menjawab pertanyaan yang dilontarkan guru. 2) Interaksi siswa dalam pembelajaran masih rendah, karena tidak semua siswa memperhatikan proses pembelajaran yang diberikan oleh guru. 3) Aktivitas siswa dalam mengikuti pembelajaran masih rendah, karena siswa dikelas hanya mencatat, mendengarkan dan melakukan kegiatan sesuai perintah guru.

Beberapa gejala juga ditemukan pada tanggal yang sama setelah mewawancarai I Gusti Nyoman Gunartha, S.Pd selaku guru mata pelajaran matematika di kelas IV. Berdasarkan hasil wawancara diketahui bahwa dari sekian materi matematika yang ada di kelas IV salah satu materi yang dianggap sulit adalah materi tentang pembelajaran pecahan. Materi ini dianggap sulit karena guru mengalami kendala dalam menanamkam konsep pecahan kapada siswa. Terbatasnya media pembelajaran yang ada di sekolah, sehingga guru sulit untuk menjelaskan apa yang ingin disampaikan kepada siswa. Walaupun dapat dijelaskan kadang-kadang siswa tidak mengerti tentang apa yang disampaikan guru, sehingga siswa merasa jenuh dan kurang tertarik terhadap materi yang diajarkan dan kegiatan pembelajaran di kelas menjadi kurang efektif dan efesien.

Permasalah di atas diperkuat oleh data riil di lapangan yang ditemukan setelah diberikannya tes awal terkait dengan materi pecahan. Banyak siswa yang mengalami kesalahan dalam menjawab tes awal yang diberikan. Misalnya ketika siswa menulis lambang pecahan yang diarsir dari gambar di bawah ini.

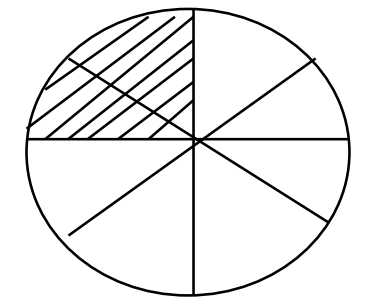

Gambar 1 Contoh Lambang Pecahan

Siswa kebanyakan menjawab nilai pecahannya adalah $\frac{2}{6}$, ada juga yang menjawab $\frac{6}{2}$ dan hanya beberapa orang siswa yang menjawab benar dengan menulis lambang pecahannya adalah $\frac{2}{8}$. Dalam menulis lambang pecahan, siswa mengalami kekeliruan seperti menulis lambang pecahan setengah yang ditulis adalah $\frac{1}{5}$. Di dalam memberi tanda $>$, =, atau $<$ untuk membandingkan nilai dari suatu pecahan masih terdapat beberapa siswa yang belum sepenuhnya benar dalam mengerjakan soal, misalnnya $\frac{3}{5} \ldots \ldots .$. 
$\frac{3}{4}$. Banyak siswa yang menjawab tiga per lima yang lebih besar, disebabkan karena siswa mengerjakan soal diatas tidak menggunakan KPK dari masing-masing penyebutnya. Hasil jawaban siswa yang demikian menunjukan bahwa pemahaman siswa terhadap materi pecahan sangat kurang. Hal tersebut terbukti dari rendahnya aktivitas belajar siswa dalam mengikuti pembelajaran dan hasil belajar siswa cendrung menurun dari kreteria ketuntasan minimal (KKM) yang ditetapkan sekolah ini yakni sebesar 65 untuk mata pelajaran matematika. Pernyataan itu terbukti dari data awal tentang hasil belajar pecahan yang didapat dari guru menunjukkan bahwa 18 siswa mendapat nilai dibawah 65 dan hanya 10 orang siswa yang dinyatakan tuntas dengan rata-rata skor hasil belajar pecahan siswa adalah 48,75\%.

Pecahan merupakan bagian integral dan merupakan konsep yang memerlukan latar belakang dan kematangan yang tinggi untuk dapat dipahami oleh siswa. Disamping itu, guru membutuhkan waktu lebih lama untuk menyajikan materi pecahan dibandingkan materi pelajaran matematika yang lain. Di Sekolah Dasar tekanan utama terletak pada pengembangan konsep intuitif pecahan melalui kegiatan bekerja dengan media, misalanya daerah segi banyak, ruas garis, garis dan himpunan diskrit (Sutawidjaja,1992).

Berdasarkan kesulitan pembelajaran yang dialami siswa, maka didiskusikanlah permasalah tersebut dengan guru mata pelajaran matematika di kelas IV. Untuk memperbaiki kesulitan pembelajaran yang dialami oleh siswa, maka diadakan perbaikan pola pembelajaran untuk meningkatkan aktivitas dan hasil belajar matematika dengan diterapkannya pendekatan kontekstual berbantuan media konkret dalam pembelajaran pecahan.

Pendekatan kontekstual adalah suatu konsep belajar di mana guru menghadirkan situasi dunia nyata ke dalam kelas dan mendorong siswa membuat hubungan antara pengetahuan yang dimiliki dengan penerapannya dalam kehidupan mereka sebagai anggota keluarga dan masyarakat (Nurhadi, dkk, 2004). Dari pengertian tersebut yang dimaksud dengan pendekatan kontekstual dalam penelitian ini adalah suatu proses kegiatan pembelajaran di kelas, dengan menggunakan media-media konkret yang ada dekat dilingkungan siswa, yang nantinya mempermudah guru di dalam menyampaikan materi pembelajaran pecahan kepada siswa. Media konkret dalam penelitian ini dapat diartikan sebagai berwujud, tampak, nyata, benar-benar ada yang bisa siswa perhatikan dengan menggunakan alat indra dan siswa tidak menghayal dengan apa yang dipelajarinya. Pembelajaran akan menjadi menarik dan menyenangkan, karena guru menerapkan pendekatan kontekstual dengan menghadirkan media konkret yang ada di sekitar lingkungan siswa, khususnya pada materi pembelajaran pecahan.

Melalalui penerapan pendekatan kontekstual berbantuan media konkret dalam pembelajaran pecahan, setidaknya memberikan kesempatan kepada siswa untuk memanipulasi benda-benda nyata yang dapat membuat siswa aktif dalam kegiatan pembelajaran. Hal tersebut akan dapat meningkatkan aktivitas dan hasil belajar matematika khususnya pada materi pembelajaran pecahan bagi siswa.

Bedasarkan latar belakang masalah yang telah diuraikan di atas, maka dirancanglah suatu penelitan yang berjudul Penerapan Pendekatan Kontekstual Berbantuan Media Konkret Untuk Meningkatkan Aktivitas Dan Hasil Belajar Matematika Bagi Siswa Kelas IV Semester II Sekolah Dasar Nomor 1 Blahkiuh Kecamatan Abiansemal Kabupaten Badung Tahun Pelajaran 2010/2011.

\section{Metode}

Jenis penelitian ini tergolong Penelitian Tindakan Kelas (PTK) yang dilaksanakan pada semester genap dari bulan Januari sampai bulan Pebruari 2011 di Sekolah Dasar Nomor 1 Blahkiuh. Penelitian ini mengambil tempat di Sekolah Dasar Nomor 1 Blahkiuh tahun pelajaran 2010/2011, dan subyek dari penelitian ini adalah siswa kelas IV semester II tahun pelajaran 2010/2011. Jumlah siswa yang menjadi subyek penelitian adalah 28 orang dengan rincian 13 perempuan dan 15 laki-laki. Subyek ini dipilih karena berdasarkan hasil observasi dan wawancara yang telah dilakukan terlihat kualitas proses pembelajaran matematika pada siswa kelas IV masih rendah. Hal ini mengingat bahwa perkembangan pola berfikir dan perkembangan mental siswa sekolah dasar masih labil dalam pemahaman konsep sehingga perlu untuk dimantapkan

Rancangan Penelitian tindakan kelas dilaksanakan dalam beberapa siklus. Penelitian tindakan sebagaimana dikemukakan oleh Kemmis dan Taggart (dalam Zuriah, 2005) merupakan penelitian yang bersiklus, yang terdiri dari empat tahapan yaitu, (1) rencana, (2) tindakan, (3) observasi, dan (4) refleksi.

Untuk mengumpulkan data dalam penelitian ini menggunakan dua metode yaitu: 1) metode observasi dan 2) metode tes. Dalam penelitian ini, metode observasi digunakan untuk mengumpulkan data tentang aktivitas belajar matematika siswa yang mencakup keaktifan siswa dalam proses pembelajaran matematika. Untuk itu metode observasi digunakan untuk mengamati aktivitas siswa dalam proses pembelajaran. observasi yang dilakukan sesuai dengan deskripsi aktivitas belajar menggunakan format lembar observasi aktivitas belajar matematika pada pembelajaran pecahan. Kemudian hasil evaluasi itu dirata-ratakan, dan data rata-rata tersebut kemidian dijadikan data untuk dapat di analisis. 
Lembar observasi yang digunakan yaitu mancakup bagaimana keaktifan siswa dalam mengikuti proses pembelajaran di kelas khususnya pada materi pembelajaran pecahan. Setiap kegiatan yang diobservasikan dikategorikan ke dalam kualitas yang sesuai yaitu dengan memberikan tanda $(\sqrt{ })$ pada kolom yang sesuai. Tes dalam penelitian ini digunakan untuk mengukur hasil belajar matematika siswa kelas IV adalah butir-butir tes sesuai dengan pokok bahasan yang telah diberikan. Agar butir-butir tes dapat mengukur tujuan pembelajaran yang diharapkan maka perlu dibuatkan kisi-kisi.

Data yang telah dikumpulkan baik dalam data skor aktivitas maupun data skor hasil belajar siswa, akan dianalisis dengan menggunakan metode analisis deskriptif kuantitatif. Hasil analisis persentase tingkat aktivitas belajar pecahan siswa yang diperoleh selanjutnya dikonversikan ke dalam Patokan Acuan Penilaian (PAP) skala lima dengan berpedoman pada kreteria seperti table 1 berikut ini.

\begin{tabular}{cc} 
Tabel 1 Kategori Penggolongan Data Aktivitas Belajar \\
\cline { 2 - 2 } Tingkat Penguasaan & Kategori \\
$(\%)$ & Sangat Aktif \\
\hline $85-100$ & Aktif \\
$70-84$ & Cukup Aktif \\
$50-69$ & Kurang Aktif \\
$30-49$ & Sangat Kurang Aktif \\
$0-29$ & Sumber: \\
\hline
\end{tabular}

Indikator keberhasilan dari penelitian ini jika ditinjau dari aktivitas belajar adalah: (1) adanya peningkatan aktivitas belajar pecahan pada siswa, dengan ketentuan minimal sebanyak $70 \%$ dari jumlah siswa keseluruhan aktivitas belajar pecahannya meningkat, (2) aktivitas siswa cenderung meningkat ke kategori aktif atau sangat aktif, atau dengan kata lain rata-rata persentase aktivitas belajar pecahan siswa mencapai $70 \%$.

Analisis data hasil belajar dilakukan setelah terkumpulnya data yang diperoleh melalui hasil tes. Selanjutnya data hasil belajar dianalisis secara diskriptif kuantitatif Hasil analisis persentase tingkat hasil belajar pecahan bagi siswa yang diperoleh selanjutnya dikonversikan ke dalam Patokan Acuan Penilaian (PAP) skala lima dengan berpedoman pada kreteria seperti table 2 berikut ini.

\begin{tabular}{cc}
\multicolumn{2}{c}{ Tabel 2 Kategori Penggolongan Data Hasil Belajar } \\
\hline $\begin{array}{c}\text { Tingkat Penguasaan } \\
(\%)\end{array}$ & Kategori \\
\hline $85-100$ & Sangat Baik \\
$70-84$ & Baik \\
$50-69$ & Cukup \\
$30-49$ & Kurang \\
$0-29$ & Sangat Kurang \\
\hline
\end{tabular}

Sumber: diadaptasi dari Agung (1997)

Indikator keberhasilan dari penelitian ini jika ditinjau dari hasil belajar adalah: (1) adanya peningkatan hasil belajar pecahan bagi siswa, dengan ketentuan minimal sebanyak 70\% dari jumlah siswa keseluruhan hasil belajar pecahannya meningkat, (2) setelah diterapkannya pendekatan kontekstual berbantuan media konkret dalam pembelajaran pecahan kemampuan siswa cenderung meningkat ke kategori baik atau sangat baik.

\section{Hasil Dan Pembahasan}

Berdasarkan hasil observasi yang telah dilaksanakan dalam kegiatan pembelajaran, maka dapat dirangkum beberapa hal sebagai berikut. 1) Dalam beberapa kali pertemuan selama siklus I, ada beberapa siswa yang tampak aktif dan selebihnya tampak kurang aktif serta kurang antusias dalam mengikuti pembelajaran. 2) Penggunaan media dalam diskusi kelompok belum berjalan maksimal karena siswa belum terbiasa dalam menggunakan media pembelajaran, beberapa siswa tidak berkonsentrasi di dalam mengikuti pembelajaran serta terbatasnya waktu dalam kegiatan pembelajaran.

Berdasarkan hasil pengamatan tentang aktivitas dan hasil belajar matematika materi pecahan saat pembelajaran berlangsung dengan diterapkannya pendekatan kontekstual berbantuan media konkret pada mata pelajaran matematika kelas IV semester II dalam empat kali pertemuan diperoleh sebagai berikut. 1) Data mengenai aktivitas belajar siswa dapat diperoleh dengan melakukan pengamatan 
melalui lembar observasi. Adapun hasil dari pengamatan aktivitas belajar pecahan bagi siswa tersaji melalui tabel dibawah ini.

Tabel 3 Data Skor Aktivitas Belajar Siswa kelas IV Semester II SD N 1 Blahkiuh pada Siklus I

\begin{tabular}{|c|c|c|c|c|c|c|c|}
\hline No & $\begin{array}{l}\text { Kode } \\
\text { Subjek }\end{array}$ & $\begin{array}{l}\text { Skor } \\
\text { I }\end{array}$ & Pertemuan & $\begin{array}{l}\text { Skor } \\
\text { II }\end{array}$ & Pertemuan & Skor Pertemuan III & $\begin{array}{l}\text { Rata-rata } \\
(\mathrm{X})\end{array}$ \\
\hline 1. & 01 & & 5 & & 5 & 6 & 5.3 \\
\hline 2. & 02 & & 4 & & 6 & 7 & 5,7 \\
\hline 3. & 03 & & 5 & & 7 & 8 & 6.7 \\
\hline 4. & 04 & & 4 & & 6 & 7 & 5.7 \\
\hline 5. & 05 & & 6 & & 7 & 8 & 7 \\
\hline 6. & 06 & & 5 & & 7 & 7 & 6.3 \\
\hline 7. & 07 & & 4 & & 5 & 6 & 5 \\
\hline 8. & 08 & & 5 & & 7 & 8 & 6.7 \\
\hline 9. & 09 & & 6 & & 7 & 8 & 7 \\
\hline 10. & 10 & & 7 & & 7 & 7 & 7,3 \\
\hline 11. & 11 & & 5 & & 6 & 7 & 6 \\
\hline 12. & 12 & & 6 & & 5 & 7 & 6 \\
\hline 13. & 13 & & 6 & & 6 & 6 & 6 \\
\hline 14. & 14 & & 6 & & 7 & 8 & 7 \\
\hline 15. & 15 & & 6 & & 7 & 7 & 7,3 \\
\hline 16. & 16 & & 5 & & 7 & 8 & 6.7 \\
\hline 17. & 17 & & 4 & & 5 & 7 & 5.3 \\
\hline 18. & 18 & & 5 & & 7 & 8 & 6.7 \\
\hline 19. & 19 & & 4 & & 6 & 8 & 6 \\
\hline 20. & 20 & & 4 & & 6 & 7 & 5,7 \\
\hline 21. & 21 & & 5 & & 6 & 8 & 6.3 \\
\hline 22. & 22 & & 6 & & 7 & 8 & 7 \\
\hline 23. & 23 & & 6 & & 7 & 7 & 6.3 \\
\hline 24. & 24 & & 8 & & 8 & 8 & 8 \\
\hline 25. & 25 & & 4 & & 5 & 6 & 5 \\
\hline 26. & 26 & & 6 & & 5 & 7 & 6 \\
\hline 27. & 27 & & 4 & & 6 & 7 & 5.7 \\
\hline 28. & 28 & & 7 & & 8 & 9 & 8 \\
\hline
\end{tabular}

Dari analisis data diatas maka rata-rata persentase aktivitas belajar pecahan bagi siswa pada siklus I adalah sebesar 63,3\%. Hasil analisis tingkat aktivitas belajar pecahan siswa yang diperoleh selanjutnya dikonversikan ke dalam Penilaian Acuan Patokan (PAP) skala lima dengan hasil pada rentangan 50\% - 69\% berarti pada kategori cukup aktif pada silus I. 2) Hasil belajar pecahan bagi siswa pada akhir siklus I yang diperoleh dengan menggunakan tes dapat tersaji melalui tabel di bawah ini.

Tabe 4 Data Hasil Belajar Pecahan bagi Siswa pada Siklus I

\begin{tabular}{ccc}
\hline No & Kode Subjek & Skor Hasil Belajar Siklus I \\
\hline 1. & 01 & 65 \\
2. & 02 & 50 \\
3. & 03 & 55 \\
4. & 04 & 65 \\
5. & 05 & 75 \\
6. & 06 & 65 \\
7. & 07 & 65 \\
8. & 08 & 65 \\
9. & 09 & 65 \\
10. & 10 & 65 \\
11. & 11 & 60 \\
12. & 12 & 55 \\
13. & 13 & 50 \\
14. & 14 & 80
\end{tabular}




$\begin{array}{lll}15 . & 15 & 75 \\ 16 . & 16 & 65 \\ 17 . & 17 & 65 \\ 18 . & 18 & 65 \\ 19 . & 19 & 50 \\ 20 . & 20 & 50 \\ 21 . & 21 & 65 \\ 22 . & 22 & 70 \\ 23 . & 23 & 65 \\ 24 . & 24 & 70 \\ 25 . & 25 & 40 \\ 26 . & 26 & 85 \\ 27 . & 27 & 65 \\ 28 . & 28 & 90\end{array}$

Untuk menentukan kreteria hasil belajar pecahan bagi siswa dapat digunakan pada tabel 4 . Berdasarkan hasil analisis data di atas maka hasil belajar matematika materi pecahan siswa pada siklus I terletak di antara rentangan 50\% - 69\% berarti pada kategori cukup

Mencermati data diatas dengan skor rata-rata kelas pada siklus I, di dapat hasil bahwa rata-rata kelas mencapai 64,28\% yang berada pada kategori cukup. jika dilihat dari PAP skala lima, maka skor ratarata kelas tergolong cukup sehingga nilai rata-rata kelas belum mencapai target minimal yang telah ditentukan yaitu sebesar $65 \%$.

Berdasarkan hasil pengamatan dan yang diperoleh sampai akhir siklus I, terdapat beberapa masalah yang menyebabkan aktivitas dan hasil belajar siswa berada pada kreteria cukup aktif. Setelah dilakukannya analisis maka dapat direfleksikan beberapa hal sebagai berikut. 1) Bahasa yang digunakan guru sulit dimengerti oleh siswa. 2) Secara umum kegiatan pembelajaran yang tersaji dalam LKS dengan dibantu menggunakan media pembelajaran belum bisa berjalan optimal sesuai dengan rencana peneliti. Disebabkan karena siswa masih terbiasa dengan pola belajar lama. 3) Kelompok yang dibentuk masih bersifat homogen, yang pintar dengan yang pintar dan yang siswa yang memilki pengetahuan kurang dengan siswa yang memiliki pengetahuan kurang juga. Selama proses pembelajaran, aktivitas belajar siswa masih tampak rendah. Hal ini disebabkan karena siswa belum terbiasa berdiskusi dalam kelompok. Karena selama ini, siswa hanya mendapat penjelasan langsung dari guru dan tidak pernah mengaitkan pembelajaran dengan dunia nyata siswa. 4) Saat menjawab soal siswa belum percaya diri akan pekerjaanya sendiri dan hanya menanti jawaban dari temanya. Tidak semua kelompok dapat menyajikan hasil kerjanya karena waktu pembelajaran lebih banyak dihabiskan dalam diskusi kelompok.

Disamping kelemahan atau kekurangan yang ditemukan diatas, keberhasilan juga ditemukan terbukti dari beberapa orang siswa tampak aktif dalam proses pembelajaran. Itu terbukti dari antusias siswa dalam mengikuti pembelajaran dari pertemuan I ke pertemuan berikutnya dapat terjadinya suau peningkatan. Untuk hasil belajar pecahan pada siswa juga ada beberapa orang siswa yang mendapat nilai dari diatas KKM. Akan tetapi perlu diadakan suatu pola perbaikan pengajaran di siklus II.

Berdasarkan hasil refleksi siklus I di atas, dengan mengetahui kekurangan-kekurangan di dalam pelaksanan pembelajaran dengan menerapakan pendekatan kontekstual berbentuan media konkret, maka penelitian berdiskusi dengan guru untuk merancang perbaikan tindakan yang selanjutnya diterapkan pada siklus II untuk lebih mengoptimalkan hasil yang diperoleh. Berikut adalah gambar diskusi antara guru dengan peneliti untuk upaya-upaya perbaikan pola pengajaran di siklus II.

Berdasarkan hasil observasi yang diperolah saat melakukan pembelajaran di siklus II, maka dapat disampaikan beberapa hal sebagai berikut. 1) Rata-rata aktivitas belajar pecahan siswa pada siklus II sudah banyak mengalami peningkatan. Ini terbukti dari 24 siswa yang aktif dan antusias dalam menyelesaikan tugas yang diberikan. Kerjasama kelompok/kreativitas siswa dalam menggunakan media sudah mengalami peningkatan hal ini terlihat dari keseriusan siswa dalam mengikuti pembelajaran dan di akhir kegiatan secara keseluruhan siswa sudah bisa menyimpulkan materi pembelajaran. Sehingga pembelajaran dikelas menjafi efektif dan menyenangkan. 2) Dalam mengerjakan soal latihan, siswa sudah bisa bekerja mandiri namun ada tiga sampai empat orang siswa yang masih ragu-ragu akan jawabanya sendiri. Tetapi secara keseluruhan siswa sudah bisa bekerja sendiri dalam menjawab tes evaluasi.

Dari hasil pengamatan tentang aktivitas dan hasil belajar matematika materi pecahan saat pembelajaran berlangsung dengan diterapkannya pendekatan kontekstual berbantuan media konkret pada mata pelajaran matematika kelas IV semester II dalam empat kali pertemuan diperoleh sebagai 
berikut. 1) Data mengenai aktivitas belajar siswa dapat diperoleh dengan melakukan pengamatan melalui lembar observasi. Adapun hasil dari pengamatan aktivitas belajar pecahan bagi siswa tersaji melalui tabel dibawah ini.

\begin{tabular}{|c|c|c|c|c|c|}
\hline No & Kode Subjek & $\begin{array}{c}\text { Skor Pertemuan } \\
\text { I }\end{array}$ & $\begin{array}{c}\text { Skor } \\
\text { Pertemuan II }\end{array}$ & $\begin{array}{c}\text { Skor } \\
\text { Pertemuan III }\end{array}$ & $\begin{array}{c}\text { Rata-rata } \\
(\mathrm{X})\end{array}$ \\
\hline 1. & 01 & 7 & 8 & 8 & 7,7 \\
\hline 2. & 02 & 8 & 8 & 7 & 7,7 \\
\hline 3. & 03 & 7 & 8 & 8 & 7.7 \\
\hline 4. & 04 & 7 & 8 & 9 & 8 \\
\hline 5. & 05 & 8 & 8 & 9 & 8,3 \\
\hline 6. & 06 & 7 & 8 & 8 & 7,7 \\
\hline 7. & 07 & 6 & 8 & 9 & 7,7 \\
\hline 8. & 08 & 8 & 8 & 9 & 8,3 \\
\hline 9. & 09 & 7 & 8 & 8 & 7,7 \\
\hline 10. & 10 & 7 & 8 & 8 & 7,7 \\
\hline 11. & 11 & 8 & 7 & 8 & 7,7 \\
\hline 12. & 12 & 6 & 7 & 7 & 6,7 \\
\hline 13. & 13 & 7 & 8 & 8 & 7,7 \\
\hline 14. & 14 & 8 & 9 & 9 & 8,7 \\
\hline 15. & 15 & 6 & 8 & 8 & 7,3 \\
\hline 16. & 16 & 8 & 7 & 8 & 7,7 \\
\hline 17. & 17 & 6 & 7 & 8 & 7 \\
\hline 18. & 18 & 8 & 7 & 9 & 8 \\
\hline 19. & 19 & 7 & 8 & 8 & 7,7 \\
\hline 20. & 20 & 6 & 7 & 7 & 6,7 \\
\hline 21. & 21 & 7 & 8 & 8 & 7,7 \\
\hline 22. & 22 & 7 & 8 & 9 & 8 \\
\hline 23. & 23 & 7 & 8 & 8 & 7,7 \\
\hline 24. & 24 & 9 & 9 & 9 & 9 \\
\hline 25. & 25 & 7 & 6 & 7 & 6,7 \\
\hline 26. & 26 & 8 & 8 & 9 & 8,3 \\
\hline 27. & 27 & 7 & 8 & 8 & 7,7 \\
\hline 28. & 28 & 9 & 9 & 9 & 9 \\
\hline
\end{tabular}

Dari analisis data diatas maka rata-rata persentase aktivitas belajar pecahan bagi siswa pada siklus II adalah 77,8\%. Hasil analisis persentase tingkat aktivitas belajar pecahan bagi siswa yang diperoleh selanjutnya dikonversikan ke dalam Penilaian Acuan Patokan (PAP) skala lima. Berdasarkan hasil analisis data di atas maka aktivitas belajar matematika materi pecahan pada siklus II terletak diantara rentangan $70 \%$ - 84\% berarti tergolong pada kategori aktif. 2) Hasil belajar pecahan bagi siswa pada akhir siklus II yang diperoleh dengan menggunakan tes dapat tersaji melalui tabel di bawah ini.

Table 6 Data Hasil Belajar Pecahan bagi Siswa pada Siklus II

\begin{tabular}{ccc}
\hline No & Kode Subjek & Skor Hasil Belajar Siklus II \\
\hline 1. & 01 & 75 \\
2. & 02 & 70 \\
3. & 03 & 85 \\
4. & 04 & 70 \\
5. & 05 & 85 \\
6. & 06 & 75 \\
7. & 07 & 85 \\
8. & 08 & 75 \\
9. & 09 & 90 \\
10. & 10 & 65 \\
11. & 11 & 85 \\
12. & 12 & 65
\end{tabular}




\begin{tabular}{lcc}
13. & 13 & 85 \\
14. & 14 & 100 \\
15. & 15 & 75 \\
16. & 16 & 70 \\
17. & 17 & 80 \\
18. & 18 & 70 \\
19. & 19 & 70 \\
20. & 20 & 65 \\
21. & 21 & 75 \\
22. & 22 & 75 \\
23. & 23 & 85 \\
24. & 24 & 100 \\
25. & 25 & 65 \\
26. & 26 & 85 \\
27. & 27 & 75 \\
28. & 28 & 100 \\
\hline
\end{tabular}

Mencermati data diatas dengan skor rata-rata kelas pada siklus II, di dapat hasil bahwa rata-rata kelas mencapai 78,57\% yang berada pada kategori baik. Jika dilihat dari PAP skala lima, maka skor ratarata kelas tergolong baik dengan keterangan tuntas dari KKM yang telah ditentukan yaitu sebesar 65 .

Secara keseluruhan, persentase skor hasil belajar pecahan bagi siswa yang dicapai pada akhir siklus II mencapai 78,57\%. Kenyataan ini berarti kemampuan siswa dalam memahami materi pecahan dan melakukan operasi pecahan dapat digolongkan ke kategori baik dan sudah dapat mencapai indikator keberhasilan dari penelitian ini. Hasil belajar pecahan siswa yang diperoleh bisa lebih ditingkatkan dengan menerapkan pendekatan kontekstual berbantuan media konkret dengan cara lebih intensif. Dari 28 orang siswa, 11 orang siswa memenuhi kategori sangat baik, 13 orang siswa memenuhi kategori baik, dan 4 orang siswa mencapai kategori cukup. Bila dibandingkan dengan hasil penelitian pada siklus I, telah terjadi peningkatan ke kreteria yang lebih baik .

Berdasarkan hasil data yang diperoleh sampai pada akhir siklus II, dapat direfleksikan beberapa hal sebagai berikut. 1) Melalui kegiatan belajar dengan mengaitkan masalah sehari-hari yang berkaitan dengan dunia nyata, dan dengan dibantu menggunakan media konkret dalam kegitan pembelajaran pecahan di dalam melakukan operasi pecahan semakin mengalami peningkatan. 2) Selama proses pembelajaran dengan penerapan pendekatan kontekstual berbantuann media konkret, cendrung mengalami suatu peningkaatan seperti antusiasme, keaktifan, kreatifitas, dan interaksi siswa. Selain itu siswa merasa senang dalam kelompok belajar kerena menemukan langsung dan solusi dari pemechan masalah dalam pembelajaran pecahan dengan menggunakan media-media konkret yang telah disediakan. 3) Diskusi kelompok masih perlu ditingkatkan lagi karena masih terdapat beberapa siswa yang yang sulit diatur dan terkadang siswa itu ketika disuruh sering melawan apa yang disampaikan, sehingga kelompok yang lain sering merasa tergangu. 4) Dalam mengerjakan soal penjumlahan dan pengurangan pecahan, terdapat kendala yang dialami oleh siswa karena siswa lansung menjumlahkan tampa mencari KPK dari masing-masing penyebutnya.

Berdasarkan observasi tindakan yang telah diakukan pada siklus II yang merupakan tindak lanjut dari pelaksanaan tindakan pada silus I. ternyata yang menjadi kendala selama proses tindakan pada siklus I dapat terpecahkan di siklus II. Terbukti dari adanya suatu peningkatan aktivitas dan hasil belajar pecahan bagi siswa. Adapun peningkatan persentase aktivitas belajar pecahan bagi siswa pada siklus I sebesar $63,3 \%$ dan meningkat di siklus II menjadi 77,8\% dan persentase hasil belajar pecahan bagi siswa pada siklus I adalah sebesar $64,28 \%$ dan mengalami peningkatan di siklus II menjadi 78,57\%.

Pada refleksi siklus II juga dilakukan refleksi akhir yang bertujuan untuk mengtetahi gambaran umum mengenai aktivitas dan hasil belajar pecahan siswa selama penelitian ini dilakukan. Berikut disajikan tabel mengenai aktivitas dan hasil belajar pecahan bagi siswa selama penelitian dilaksanakan. 
Table 7. Ringkasan Data Aktivitas Belajar Matematika Siswa pada Siklus I dan II

\begin{tabular}{|c|c|c|c|}
\hline Tahapan & $\begin{array}{lll}\begin{array}{l}\text { Persentase } \\
\text { pecahan }\end{array} & \text { skor aktivitas } \\
\end{array}$ & Belajar & Kategori \\
\hline Siklus I & $63,3 \%$ & & Cukup Aktif \\
\hline Siklus II & $77,8 \%$ & & Aktif \\
\hline
\end{tabular}

Tabel 8 Ringkasan Data Hasil Belajar Matematika Siswa pada Tes Awal, Siklus I dan II

\begin{tabular}{ccc}
\hline Tahapan & $\begin{array}{c}\text { Persentase Skor Hasil Belajar } \\
\text { pecahan }\end{array}$ & Kategori \\
\hline Tes Awal & $48,75 \%$ & Kurang \\
Siklus I & $64,28 \%$ & Cukup \\
Siklus II & $78,57 \%$ & Baik \\
\hline
\end{tabular}

Berdasarkan hasil penelitian yang telah dilakukan dalam dua siklus, kemampuan dan pemahaman siswa mengenai pembelajaran pecahan cendrung mengalami suatu peningkatan, mulai dari materi pengenalan pecahan, perbandingan dan pengurutan pecahan, menyederhanakan berbagai bentuk pecahan, penjumlahan pecahan dan masalah sehari-hari yang berkaitan dengan penjumlahan pecahan, pengurangan pecahan dan masalah sehari-hari yang berkaitan dengan pengurangan pecahan dan terakhir penyelesaian masalah sehari-hari yang melibatkan penjumlahan dan pengurangan pecahan. Dari hasil tes akhir siklus I masih terdapat beberapa siswa yang belum bisa menyelesaikan operasi pecahan dengan benar. Salah seorang siswa (termasuk anak yang kurang dalam pelajaran matematika), di dalam mengerjakan soal menulis lambang pecahan mengalami kekeliruan seperti:

Tulislah lambang pecahan setengah yang ditulis adalah $\frac{1}{5}$ karena dia mengira kalau bentuk desimal dari setengah adalah 0,5 karena itu dia menulis lambang pecahannya seperti diatas. Dalam memberi tanda $>$, =, atau < untuk membandingkan nilai dari suatu pecahan masih terdapat beberapa siswa yang belum sepenuhnya benar dalam mengerjakan soal, misalnnya $\frac{2}{8}$....... $\frac{1}{2}$ terdapat beberapa orang siswa yang menjawab dua per delapan yang lebih besar, karena dalam mengerjakan soal diatas, siswa tidak menggunakan KPK dari masing-masing penyebutnya.

Namun, setelah melalui proses tindakan, pada akhir siklus II secara keseluruhan siswa sudah mampu mengerjakan soal dengan benar dan mengalami peningkatan yang cukup baik. Hal ini terbukti dari penyelesaian operasi hitung pecahan mulai dari pengurangan dan penjumlahan pecahan sudah dapat dikerjakan dengan baik, seperti di bawah ini

$$
\begin{aligned}
& \frac{1}{6}+\frac{3}{5}=\frac{5}{30}+\frac{18}{30}=\frac{23}{30} \\
& \frac{9}{12}-\frac{4}{36}=\frac{27}{36}-\frac{4}{36}=\frac{23}{36}
\end{aligned}
$$

Secara keseluruhan siswa sudah bisa mengerjakan opersi pengurangan maupun penjumlahan pecahan dengan menggunakan KPK secara benar, namun masih terdapat beberapa orang siswa yang keliru karena belum hapal tentang perkalian bilangan. Namun secara keseluruhan siswa yang kurang di siklus I mengalami peningkatan di siklus II, dan kenyatan ini terbukti dari meningkatnya aktivitas dan hasil belajar pecahan bagi siswa baik selama tindakan maupun tes akhir siklus.

Aktivitas belajar pecahan bagi siswa saat diberikan tindakan mengalami suatu peningkatan. Pada siklus I rata-rata aktivitas belajar pecahan siswa adalah 6,33 dengan persentase aktivitas belajar pecahan bagi siswa adalah sebesar $63,3 \%$. Hasil aktivitas belajar pecahan bagi siswa yang diperoleh belum memenuhi target minimal yang telah ditentukan peneliti yaitu berada pada kategori aktif. Ini disebabkan karena kurangnya rasa percaya diri siswa, kurangnya siswa dalam memberi, menerima atau merespon pertanyaan atau arahan yang diberika oleh peneliti serta kuranngnya antusias siswa dalam mengikuti pembelajaran.

Bertolak dari permasalahan itu maka peneliti memperbaikai pola pengajaran dengan membenahi kelemahan maupun kekurangan yang ada di siklus I yang natinya diterapkan di siklus II dengan pola pengajaran baru hasil dari refleksi siklus I. Setelah diberikan tindakan pada siklus II selama proses pembelajaran maka rata-rata aktivitas belajar pecahan bagi siswa adalah 7,78 dengan persentase aktivitas belajar pecahan bagi siswa adalah sebesar $77,8 \%$ dan berada pada katergori aktif. Ini terbuti adanya suatu peningkatan aktivitas belajar pecahan bagi siswa. Sehingga aktivitas belajar matematika materi pecahan siswa meningkat di siklus II dan berada pada katergori aktif. 
Sejalan dengan meningkatnya aktivitas belajar pecahan bagi siswa, maka untuk hasil belajar pecahan bagi siswa menunjukkan adanya suatu peningkatan. Data hasil tes awal atau sebelum diberi tindakan menunjukkan bahwa 18 siswa mendapat nilai dibawah 65 dan hanya 10 orang siswa yang dinyatakan tuntas. Pernyataan itu terbukti dari persentase skor hasil belajar pecahan bagi siswa pada saat tes awal adalah $48,75 \%$ dan ini belum memenuhi KKM yang ada di sekolah yaitu $65 \%$. Pada siklus I terdapat 20 orang siswa yang dinyatakan tuntas atau memperoleh nilai $\geq 65$ dan 8 orang siswa belum dinyatakan tuntas atau memperoleh nilai rata-rata kurang dari 65 . Persentase hasil belajar pecahan bagi siswa sebelum diberi tindakan adalah sebesar $48,75 \%$ dan setelah diberi tindakan pada siklus I maka diperoleh rata-rata hasil belajar matematika materi pecahan sebesar 64,28 dengan persentase hasil belajar pecahan bagi siswa adalah $64,28 \%$. Itu jelas menunjukan bahwa adanya suatu peningkatan hasil belajar pecahan yang telah dialami siswa. Hal tersebut disebabkan karena siswa mau menerima pendekatan pembelajaran baru yaitu pendekatan kontekstual, dan dengan dibantu oleh media konkret yang mmberikan kesempatan kepada siswa untuk membangun sediri pengetahuannya sehingga suasana kelas menjadi kondusif. Kemudian pada siklus II terjadi peningkatan hasil belajar matematika. Ini terbukti dari rata-rata hasil belajar pecahan bagi siswa pada siklus II adalah sebesar 78,57 dengan persentase hasil belajar pecahan bagi siswa adalah sebesar 78,57\%. Dari hasil belajar pecahan bagi siswa yang diperoleh secara keseluruhan menunjukkan bahwa semua dinyatakan tuntas atau memperoleh nilai $\geq 65$.

Jika dibandingkan dengan kondisi saat pemberian tes awal, kemampuan siswa pada siklus I maupun siklus II cendrung mengalami suatu peningkatan. Ini terbukti dari meningkatnya persentase aktivitas belajar pecahan bagi siswa pada siklus II yaitu 77,8\% dan meningkatnya persentase hasil belajar pecahan bagi siswa pada siklus II sebesar 78,57\%. Ini menunjukan bahwa indikator dari penelitian ini telah berhasil dengan perolehan nilai aktivitas maupun hasil belajar siswa diatas KKM yaitu sebesar 65 . Peningkatan tersebut terjadi karena siswa mendapat bimbingan yang intensif dalam mencari penyelesaian masalah-masalah kontekstual yang tersaji dalam LKS. Dalam menyelesaikan masalah siswa diberikan media pembelajran dalam diskusi kelompok dan memberi kesempatan kepada siswa untuk menggali/menemukan sendiri kemampuannya sehingga pembelajaran menjadi menyenangkan dan situasi kelas menjadi kondusif.

Berdasarkan hasil pengamatan yang dilakukan selama proses pembelajaran dapat deketahui bahwa antusiasme, keaktifan, krestivitas, dan interaksi siswa selama pembelajaran semakin meningkat. Setelah dilakukannya wawancara, menunjukan bahwa, siswa merasa sangat senang dalam mengikuti pembelajaran dengan penerapan pendakatan kontekstual yang dibantu dengan digunakannya media konkret.

Oleh karena aktivitas dan hasil belajar pecahan bagi siswa sudah mengalami suatu peningkatan maka penelitian ini dihentikan. Namun untuk lebih mengoptimalkan pemahaman dan kemampuan siswa dalam pembelajaran pecahan, penerapan pendekatan kontekstual berbantuan media konkret ini perlu dilakukan secara rutin. dari penjelasan diatas dapat disimpulkan bahwa dengan penerapan pendekatan kontekstual berbantuan media konkret dapat meningkatkan aktivitas belajar pecahan siswa yang nantinya bermuara pada meningkatnya suatu hasil belajar pecahan siswa.

Menurut Nurhadi, dkk (2004) menyebutkan bahwa pendekatan kontekstual adalah suatu konsep belajar dimana guru menghadirkan situasi dunia nyata ke dalam kelas dan mendorong siswa membuat hubungan antara pengetahuan yang dimiliki dengan penerapannya dalam kehidupan mereka sebagai anggota keluarga dan masyarakat. Sedangkan yang diamaksud media konkret adalah Media konkret dalam penelitian ini dapat diartikan sebagai berwujud, tampak, nyata, benar-benar ada yang bisa siswa perhatikan dengan menggunakan alat indra dan siswa tidak menghayal dengan apa yang dipelajarinya.

Jadi dengan kata lain pendekatan kontekstual dalam penelitian ini adalah suatu konsep belajar, yang dapat membantu guru untuk menghubungkan kegiatan/materi pembelajaran di kelas dengan situasi dunia nyata siswa dan mendorong siswa membuat hubungan antara pengetahuannya dalam kehidupan mereka sehari-hari. Jadi dengan kata lain pendekatan kontekstual ini sangat cocok diterapkan dalam penelitian ini, karena merupakan suatu konsep belajar dengan menggunakan media konkret dalam kegiatan pembelajaran yang dilakukan oleh siswa yang nantinya dapat meningkatkan aktivitas dan hasil belajar serta menambah wawasan dan pengetahuan siswa dalam kehidupannya sehari-hari.

Pembelajaran akan menjadi menarik dan menyenangkan, karena guru menerapkan pendekatan kontekstual dengan menghadirkan media konkret yang ada di sekitar lingkungan siswa sehingga siswa termotivasi untuk membentuk suatu hubungan anatara pengetahuan dengan kehidupannya sehari-hari. Dalam pendekatan kontekstual ini siswa dapat melatih dirinya untuk dapat berfikir secara kritis, logis serta menjadi siswa yang kreatif dengan harapan tercapainya aktivitas dan hasil belajar yang maksimal.

Adapun beberapa kendala yang ditemukan pada II yaitu yang menjadi kekurangan-kekurangan terlihat dari sulitnya siswa dalam mengoperasikan penjumlahan dan pengurangan pecahan. Karena siswa lansung menjumlahkan atau mengurangkan pecahan tersebut tampa menyamakan atau mencari KPK dari 
masing-masing penyebutnya. Sehingga hasil yang diperoleh belum bisa dikatakan optimal. Maka perlu dioptimalkan lagi kemampuan atau pemahaman siswa dalam melakukan operasi pecahan, melalui penerapan pendekatan kontekstual berbantuan media konkret dalam pembelajaran pecahan agar lebih dioptimalkan dan dilakukan secara rutin atau berkelanjutan.

Beberapa kendala juga ditemukan pada saat pembentukan maupun diskusi kelompok memerlukan waktu lebih banyak karena siswa belum terbiasa diberi permasalahan dan berusaha menemukan sendiri jawabannya, itu disebabkan karena siswa dari dulunya hanya belajar melalui ceramah. Situasi kelas cendrung gaduh karena siswa baru menerima pendekatan kontekstual berbantuan media konkret sehingga waktu yang digunakan dalam kelas menjadi agak lama dari alokasi waktu yang ada dalam RPP.

\section{Simpulan Dan Saran}

Berdasarkan hasil penelitian dan pembahasan yang telah diuraikan, maka dapat ditarik suatu kesimpulan sebagai berikut. 1) Penerapan pendekatan kontekstual berbantuan media konkret dapat meningkatkan aktivitas belajar matematika materi pecahan bagi siswa kelas IV semester II Sekolah Dasar Nomor 1 Blahkiuh. Terbukti dari rata-rata aktivitas belajar pecahan bagi siswa secara klasikal pada siklus I adalah sebesar 6,33 dengan persentase aktivitas belajar pecahan bagi siswa sebesar 63,3\% dan berada pada kategori cukup aktif. Pada siklus II rata-rata aktivitas belajar pecahan bagi siswa adalah 7,78 dengan persentase aktivitas belajar pecahan bagi siswa adalah sebesar $77,8 \%$ dengan kategori aktif. Ini menunjukan bahwa adanya suatu peningkatan aktivitas belajar pecahan bagi siswa sebesar $14,5 \%$ dari siklus I sampai pada siklus II. 2) Penerapan pendekatan kontekstual berbantuan media konkret dapat meningkatkan hasil belajar matematika materi pecahan bagi siswa kelas IV semester II Sekolah Dasar Nomor 1 Blahkiuh. Hal ini dapat dilihat dari hasil belajar pecahan siswa yang terus meningkat. Persentase hasil belajar pecahan bagi siswa pada tes awal hanya mencapai $48,75 \%$ dan terletak pada kategori kurang, dan mengalami peningkatan pada siklus I menjadi 64,28 dengan persentase hasil belajar pecahan bagi siswa adalah $64,28 \%$ dan berada pada kategori cukup. Rata-rata persentase peningkatan hasil belajar pecahan bagi siswa dari tes awal sampai pada siklus I adalah sebesar 15,53\%. Setelah dilakukannya perbaikan pola pengajaran/tindakan pada siklus II, maka rata-rata hasil belajar pecahan bagi siswa meningkat hingga mencapai 78,57 dengan persentase hasil belajar pecahan bagi siswa pada siklus II adalah $78,57 \%$ dan berada pada kategori baik. Rata-rata persentase peningkatan hasil belajar pecahan bagi siswa dari siklus I sampai pada siklus II adalah sebesar 14,29\%.

Adapun beberapa saran yang dapat dikemukakan dari penelitian ini adalah sebagai berikut. 1) Bagi guru sekolah dasar di Sekolah Dasar Nomor 1 Blahkiuh diharapkan untuk dapat menerapkan pendekatan kontekstual berbantuan media konkret dalam pembelajaran pecahan. Karena terbukti dari penerapan pendekatan kontekstual berbantuan media konkret dapat meningkatkan aktivitas dan hasil belajar pecahan bagi siswa. Dalam kegiatan pembelajaran dikelas semestinya siswalah yang harus lebih aktif dalam menemukan sendiri pengetahuannya dan guru hanya membantu untuk memfasilitasi kegiatan pembelajaran. Dengan siswa menemukan sendiri pengetahuannya dalam kelompok belajar, secara tidak langsung suasana kelas akan menjadi kondusif sehingga aktivitas dan hasil belajar siswa dapat tercapai secara optimal dan maksimal. 2) Bagi peneliti lain diharapkan dalam penerapan pendekatan kontekstual berbantuan media konkret untuk lebih mendalami dengan lebih banyak menghadirkan dunia nyata ke dalam kelas yang nantinya diharapkan untuk bisa diterpakan di sekolah lain. Sehingga apa yang menjadi kendala-kendala dalam penelitian ini dapat terpecahkan secara optimal dan maksimal. Jika pembelajaran sudah dilakukan sedemikian rupa, maka akan tercapainya suatu peningkatan aktivitas dan hasil belajar yang optimal dan maksimal.

\section{Daftar Pustaka}

Arsyad, Azhar. 1997. Media Pengajaran, Jakarta: Raja Grafindo Persada.

Agung, A.A.Gede. 1997. Pengantar Evaluasi Pengajaran. Singaraja: STKIP Singaraja.

------, 1999. Metodalogi Penelitian Pendidikan, Singaraja: STKIP.

------, 2005. Metodologi Penelitian Pendidikan. Singaraja: FIP IKIP Negeri Singaraja.

Depdiknas. 2002. Pedoman Studi IKIP Negeri Singaraja Fakultas MIPA. Singaraja: Depdiknas.

2004. Kurikulum Pendidikan Dasar. Jakarta: Depdiknas. 
Dimyati dan Moedjiono. 1994. Belajar dan pembelajaran. Jakarta: Rineka Cipta.

Hudojo H. 1988. Belajar Mengajar dengan penggunaan alat peraga dalam pembelajaran Matematika. Jakarta: Depdikbud.

Hamalik, Oemar. 2001. Proses Belajar Mengajar. Bandung: PT Bumi Aksara.

Kunandar. 2007. Implementasi KTSP dan Persiapan Menghadapi Sertifikasi Guru. Jakarta: PT. Raja Grafindo Persada.

Nurkancana dan Sunartana. 1990. Evaluasi Hasil Belajar. Surabaya: Usaha Nasional.

Nurhadi, dkk. 2004. Pembelajaran kontekstual dan penerapannya dalam KBK. Malang: Universitas Negeri Malang.

Pitajeng. 2006. Pembelajaran Matematika yang Menyenangkan. Jakarta: Depdiknas.

Sudjana, Nana dan Ahmad Rivai. 1989. Media Pengajaran. Bandung: Sinar Baru.

Suarjana, I Made. 2001. Buku Ajar Pendidikan Matematika I. Singaraja: IKIP Singaraja.

Suarjana, I Made dkk. 2007. Penerapan Pembelajaran Matematika Realistik Untuk Meningkatkan Prestasi Matematika Siswa Kelas III Sekolah Dasar Nomor I Paket Agung Singaraja. Fakultas Ilmu Pendidikan Universitas Pendidikan Ganesha Singaraja.

Sudarma, I Komang \& Desak Putu Parmiti. 2007. Modul Media Pembelajaran SI PGSD. Singaraja: FIP UNDIKSHA.

Suartama, I Kadek. 2008. Bahan Ajar Media Pembelajaran. Singaraja: UNDIKSHA.

Sudiarta, I Wayan. 2010. Upaya Peningkatan Hasil Belajar Matematika Melalui Penggunaan Model Pembelajaran Kontekstual Pada Siswa Kelas IV Semester I SD Negeri 2 Sukadana Kecamatan Kubu Tahun Pelajaran 2009/2010. Skripsi (tidak diterbitkan). Jurusan PGSD FIP Undiksha singaraja.

Sudiana, I Ketut. 2004. Pembelajaran Matematika Sekolah Dasar Tahap Awal. Departemen Pendidikan Nasional.

Suryabrata, Sumadi. 2002. Psikologi Pendidikan. Jakarta: PT. Raja Grafindo Persada.

Sutawidjaja, Akbar,dkk. 1992. Pendidikan matematika II. Jakarta: Direktorat Jendral Pendidikan Tinggi.

Sudjana, Nana. 2004. Penilaian Hasil Proses Belajar Mengajar. Bandung: PT Remaja Rosdakarya.

Suyanto, dkk. 1997. Pedoman Pelaksanaan Penelitian Tindakan Kelas (PTK). Pengenalan Penelitian Tindakan Kelas. Yogyakarta: IKIP Yogyakarta.

Sriyani, Nyoman. 2010. Penerapan Pendekatan Kontekstual Untuk Meningkatkan Hasil Belajar Matematika Dalam Memecahkan Soal Cerita Pada Siswa Kelas II Semester I SD No. 4 Tukad Sumaga Kecamatan Gerokgak Kabupaten Buleleng Tahun Pelajaran 2009/2010. Skripsi (tidak diterbitkan). Jurusan PGSD FIP Undiksha Singaraja.

Zuriah, Nurul. 2005. Metodologi Penelitian Sosial dan Pendidikan. Malang: Bumi Aksara. 